\title{
Contextual-Participative e-Government Implementation Model: A Case Study of the Office of Demographic and Citizen Data Records of Makassar
}

\author{
Frida Chairunisa
}

Muh. Tahir Malik

Muh. Asfah Rahman

Rifdan

Department of Public Administration, Universitas Negeri Makassar, Jl. Bonto Langkasa Kampus Gunung Sari Baru Postal Code 90222, Makassar, South Sulawesi, Indonesia; fchairunnisa@yahoo.com, m.tahir_malik@yahoo.co.id asfah_rahman@yahoo.com, rifdan@unm.ac.id

\section{Doi:10.5901/mjss.2016.v7n1s1p345}

\section{Abstract}

Today, e-Government has been increasingly practiced in the private and public sectors in both developed and developing countries. However, in the context of Indonesian public sector, it is questionable as to how effective e-Government is in supporting the delivery of quality public service. This study assumes that implementation model has something to do with the effectiveness of e-Government. It examines a mismatch between theorized e-Government implementation model and an actual model emerging from the context of an Indonesian public sector organization. The study found that the mismatch was influenced by the cultural and historical environment of the organization, which contributes to the ineffectiveness of eGovernment implementation. In order to ensure effectiveness, the study proposes a contextual-participative implementation model for the organization under investigation.

Keywords: e-Government, Public Service, Suprastructure, implementation model

\section{Introduction}

The role of Information and Communication Technologies (ICT) in improving public service (e-Government) has been widely exploited in developed worlds, and now increasingly being practiced in developing countries. In the context of Indonesia decentralized public service, e-Government plays an important role in helping local governments manage devolved functions. At the same time, it also helps the central government manage its core strategic functions at the national level.

Except for a limited number of functions remaining within the authority of the central government, all other functions have been devolved to local governments in early 2000. Many experts perceive such a grand decentralization scale overoptimistic. Some refer to this massive decentralization initiative a "big-bang". Given the paternalistic bureaucratic culture of Indonesian bureaucracy, these new tasks and increased dynamics have forced local governments to embark on eGovernment bandwagon.

In fact, the use of ICT in Indonesia can be traced back to 1976 when Palapa A1, a geostationary satellite, was launched. However, subsequent development of ICT use has not been very promising. Indonesia was in position 52 out of 55 countries included in the 2000 Information Society Index (see Chairunisa, 2010). In addition, The Division of Economy and Public Administration of the United Nations in its 2001 e-Government survey gave 1.34 points (minimal Category) for Indonesia (Ronaghan, 2002). Furthermore, based on the e-Government readiness index, Indonesia's position continues to drop from 70 in 2003 to 97 in 2012 (See The Economist Intelligence Unit, 2007, 2008, 2009; UN Global e-Government Readiness Report, 2004; United Nations E-Government Survey, 2012). Furthermore, Indonesia still struggles with some of the fundamental problems related to e-Government such as the absence of shared perception at the national level about the grand design of e-Government, inadequate human resource capacity and lack of leadership (See Salahuddin \& Rusli, 2005).

The city of Makassar is one of the local governments in Indonesia committing to utilize e-Government in supporting its public service delivery. Although Makassar was only ranked 53 of 65 cities in 2007 e-Government Survey by 
Wartaegov (2008), a survey carried out by yahoo.com in 2012 showed that $40 \%$ of Makassar population are active Internet users (Abugaza, 2014). The city of Makassar has launched a number of initiatives to exploit e-Government benefits, for example by designing e-Government Blue Print 2009-2011 (Pemkot Makassar, 2008b) and planning to build an online tax payment systems connecting the city's tax office with some major restaurants in the city (Tribun, 2009).

One of the early users of e-Government within this city is the Office of Demographic and Citizen Data Records (ODCDR) of Makassar. This office has been using ICT since 1996. Therefore, it is beneficial to investigate the eGovernment implementation model attempted by the ODCDR of Makassar. More specifically, the objective of this research is twofold: 1) to examine what the existing e-Government implementation model at the ODCDR of Makassar is, and the extent to which the model fits with the need of the ODCDR of Makassar. 2) to propose ideal implementation model for the ODCDR of Makassar.

\section{Methods and Data}

This research employs a qualitative approach to explore the complex nature of problems under investigation. Data were gathered through the use of semi-structured interviews of key informants within the ODCDR of Makassar and of its service users. Interviews were recorded with the consent of the informants using voice recorders and transcribed for analysis. In addition, review of relevant documents and direct observation were carried out to allow data triangulation. The available data were analyzed using interactive model proposed by Miles and Huberman (2009), whereby data collection, data reduction, data display, and conclusion drawing/verification were carried out repeatedly and concurrently.

\section{Result and Discussion}

\subsection{The Traditional Public Service Delivery}

In order to appreciate public service delivery in Indonesia, it is important to review the culture of its government bureaucracy briefly. Its strong paternalistic culture has characterized Indonesian public service. Seniority is highly emphasized (see, for example, Rohdewohld, 1995) and is very important in many respects. As MacAndrews (1986, p. 31) notes, "seniority and age play an important part in all relationships" in Indonesia bureaucracy. In relation to training careers, the rank determines the kinds of training programs in which a trainer can teach, or the ones that they are entitled to attend. Seniority also determines career promotion, salary entitlements, and bonuses. Virtually all other activities are determined by rank. In the end, these affect how public servants behave and relate to one another.

In the late 1990s, the demand for government reform was widespread, culminating in the toppling down of the Soeharto administration or also known as the New Order era. Some changes started taking place following the end of the New Order regime, including decentralization of government and the administrative reform. The decentralization scheme shifted the rule of the game from central government being the dominant player to the local government having to carry out so many devolved functions all at once. Due to its massive scale of reform agenda, many dubbed the regional autonomy a "big-bang" decentralization highlighting the over-optimistic nature of the reform. Many predicted that the scheme was bound to fail, but some other optimistic advocates saw the confusing period as a transition and learning period towards better public governance. After several years, the decentralization has started to take shape.

\subsection{Theoretical Foundation of e-Government Implementation}

Rana, et al. (2011) has reviewed 434 research reports and found some theoretical foundations commonly used by eGovernment researchers as the background. These include Technology Acceptance Mode (TAM), Information System Success Model, Diffusion of Innovation Theory, Unified Theory of Acceptance and Use of Technology (Venkatesh, 2003:447-454; Carter and Schaupp et al., 2012), Theory of Planned Behaviour, Extended TAM, Theory of Reasoned Action, Trust Model and Active Agent Framework based on Structuration Theory. For the current research, General Systems Theory and Institutional Theory are particularly relevant to be used as theoretical standpoints. Both theories are closely connected given that e-Government is at once a system and an institution.

Ludwig von Bertalanffy, one of the pioneers of General Systems Theory, found what has been known as Isomorphic laws suggesting that among different systems there exists similarity in characteristics, structure, formula and order (See Wahid, 2011). These similarities are used to define, determine scope, and to classify many types of systems.

Boulding (1956), describes General Systems Theory by identifying nine levels of systems: static systems (such as gene anatomy, cell), Simple Dynamic Systems with predefined movements (such as steam machine, dynamo), 
Cybernetics (such as thermostat which will function within its homeostasis), open systems which can control itself (simple living things such as bacteria and virus), genetic societal (such as plants), animals (high mobility and has selfawareness), human (has self-awareness and self-reflection), social organization (collection of individuals with his or her own roles connected by communication channels), and transcendental system (metaphysic).

Although Boulding's conceptualization of the General Systems Theory is very useful in developing fundamental understanding of the essence of systems, dividing levels of systems in such detail is too complicated for the purpose of this research. Therefore, the researcher adopted a simpler conceptualization by Porra (2005) as seen in Wahid (2011) using only three metaphors from General Systems Theory (mechanistic, organic and colony). Each system metaphor will be elaborated below.

A mechanistic System is static in nature, isolated from its environment and its structure will only change if subjected to external forces. The mechanistic systems cannot evolve as is the case for living systems. Its lifecycle can only be prolonged by replacing or repairing its parts based on its original state. When its environment changes, the mechanistic system will consequently die.

Organic Systems solve the limitation of the mechanistic systems by providing feedback and control mechanisms. An organic system may evolve and adapt to its environment incrementally so that it can survive longer than its mechanistic counterpart.

A colony system does not suffer from the same problem. A colony here is defined as a collection of individuals having similar historical, social evolution characteristics, similarity in the method of creating stability and confronting radical changes, and similarity in the local context. A colony is a complex adaptive system comprising individuals who are not functioning in isolation but rather interact with other individuals.

Implementation of e-Government can be seen or mapped into one of the General System Theory metaphors above. In general, a simple e-Government may be seen as a mechanistic system, and in contrast when it has reached advanced development stage it may be seen as a system of colony.

Another theoretical basis that is useful for this study is the Institutional Theory. This theory conceptualizes an institution as a strong and complex social structure composed of symbolic elements, social activities, and material resources. Institutional Theory can explain how collective awareness or isomorphic changes take place. It offers the following three isomorphic changes for institutions: coercive, mimetic, and normative (DiMaggio and Powell 1983).

The coercive isomorphism is similarity dictated by formal or informal forces imposed upon an organization originating from other more superior organizations to which it belongs or dependent. The pressure may also come from cultural expectations of the society where the organization is located. The normative isomorphism is similarity originating from the internal pressure of an organization to be more professional. The mimetic isomorphism is similarity dictated by a force of uncertainty driving an organization to imitate existing solutions from other organizations.

If the context of e-Government implementation, supporting factors for developing and utilizing e-Government may come from political pressure or higher level organizations or demand of the citizen for better services (coercive). For instance, the implementation of bureaucracy reform by the government of Indonesia forced government institutions to utilize electronic tools to boost efficiency, effectiveness and the quality of public services. An organization may equally decide to adopt e-Government on the basis of internal collective awareness among its members who see e-Government as a supporting instrument for delivering better services (normative). Furthermore, an organization may adopt eGovernment because of the fear to be rendered irrelevant due to rapid technological advancement, and, therefore, decides to imitate other organizations that have successfully implemented e-Government (mimetic).

Based on the two theoretical perspectives above, alternative e-Government implementation models may be generated as seen in Figure 1. When an organization implements e-Government due to external pressure and the resulting e-Government is mechanistic in nature, theoretically it can be said that the organization merely automate its functions. However, if e-Government implementation materializes because of internal need to be more professional and organic nature characterizes the e-Government, then the organization is undertaking development. Finally, when the implementation of e-Government is triggered by a radical change and the organization adapts a proven e-Government best-practice from elsewhere, the organization essentially transforms itself.

From the discussion above it can be seen that General Systems Theory and Institutional Theory can be combined and used as a theoretical basis for research on e-Government implementation model (See Figure 1). 


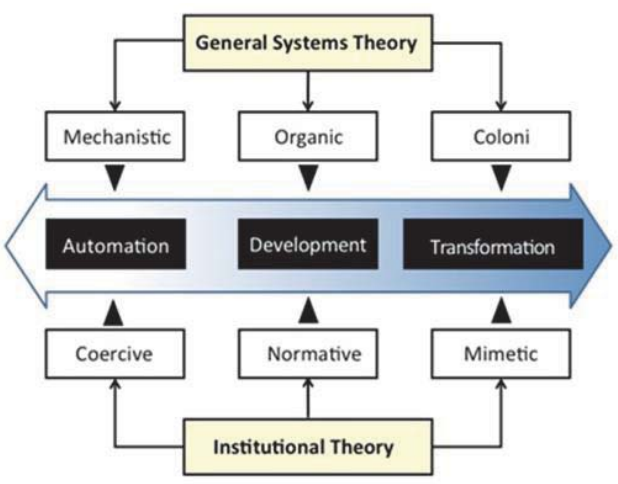

Figure 1. E-Government Implementation Model

Source: Adapted from Boulding (1956), DiMaggio and Powell (1983)

\subsection{The existing e-Government implementation model for the ODCDR of Makassar}

After discussing the theoretical and conceptual basis for the current e-Government research, it is important to consider next what the existing e-government implementation model in the ODCDR of Makassar based on the theoretical framework above is.

The discussion above suggests that from the perspective of a General Systems Theory, e-Government at the ODCDR of Makassar belongs to an "Organic Model". This can be seen from the evolutionary nature of the development process of the existing e-Government at this office. The evolutionary development process is indicated by the fact that old e-Government applications evolved into the new ones. The demographic database as a main component in the old eGovernment application is integrated into the new one. The electronic citizen ID card that is the latest application continues to use the same database. The only difference is that the number of records in the database has increased significantly due to extensive electronic data recording for Citizen ID card.

More specifically, the evolutionary process originated from the Demographic Management Information Systems (SIMDUK) which was a pioneering system developed in 1996. Due to its limitation of being unable to process citizen records, SIMDUK was then developed further and later became Demographic Management Information Systems (SIAK). This newer system was capable of handling both demographic and citizen data management. Both SIMDUK and SIAK were developed based on the central government perspective that is to help collect, at the national level, data on demography and citizen. It is important to recognize, however, that local government including the ODCDR of Makassar also has their own specific requirements in relation to demographic and citizen data management. Therefore, to take local government needs into account, some local government including this office was once allowed to develop their own application but using SIAK as the standard. The resulting application for Makassar was known as the Transitional SIAK. Based on this transitional application the central government once again developed SIAK further and made it a basis for electronic citizen card.

From the discussion above, it can be understood that the e-Government application at the ODCDR of Makassar developed gradually over time that is precisely the characteristic of an Organic Model that is the ability of a system to adapt to its operating environment. In this case, SIMDUK adapted with its environment that undertook changes in terms of policy, technology and dynamic in the society.

Nevertheless, it is important to note that the central government actually developed the e-Government implemented by the ODCDR of Makassar. The involvement of this office was limited to providing information to the central government regarding problems they encountered when operating the system so that the central government could make further upgrades.

Further analysis suggests that the above phenomenon is influenced by the paternalistic bureaucratic culture in Indonesian government discussed earlier. Chen et al. (2007) and other researchers have shown that culture has a strong influence on the success or failure of e-Government. The influence of a centralized culture that has been the feature of the Indonesian government for a long time is still in effect long after a decentralized system of government has been implemented. Raharjo in Wicaksono (n.d) indicates some obstacles to e-Government in Indonesia, including a weak culture of information sharing and documenting. When local capacity is still low, on the one hand, but the pressure to 
implement e-Government is high on the other, it is understandable if the central government takes a lead. While this topdown approach has proven to be effective especially in solving the problem of system integration, it also leaves some problems, such as local government specific needs being overlooked in the system development. Many experts have suggested otherwise that it is important to take into account the needs of users in developing electronic service delivery systems (Nygren, 2009; Wallstrom, 2009; Verdegem and Verhoest, 2009). Furthermore, this approach creates a dependency of local governments to the central government, and the sense of ownership among local government is rendered low.

From the perspective of Institutional Theory, it is clearly observable that e-Government at the ODCDR of Makassar is Coercive in nature. It is determined by the higher level of authority within the government structure. This can be seen from the dominant role of the central government through imposing policies and regulations, developing the systems, providing training for operators, and even providing some of the e-Government hardware facilities.

In this case, the ODCDR of Makassar simply uses infrastructure and technological tools made available by the central government. This is convenient for ODCDR as e-Government infrastructure in Makassar was limited (Tim TIC Indonesia, 2010). At most, they can purchase compatible applications to expand their service capacity based on the local government resource availability.

The combination between General System Theory and Institutional Theory perspectives suggests that eGovernment implementation model at the ODCDR of Makassar cannot be mapped into one of the models described in the theoretical foundation: Automation, Development, and Transformation. In the theoretical framework, mechanistic metaphor (General Systems Theory) and Coercive (Institutional Theory) produces Automation model; Organic (General Systems Theory) and Normative (Institutional Theory) produces Development model; and Colony (General Systems Theory) and Mimetic (Institutional Theory) result in Transformation model.

Analysis of data reveals that the emerging metaphors are Organic (General Systems Theory) and Coercive (Institutional Theory) which are not assumed to co-exist under the theoretical framework, thus does not produce a stylized model (See Figure 2).

The data suggests that on the surface the ODCDR of Makassar seems to have successfully developed its eGovernment incrementally (Organic) while in fact it was developed by the central government. Further, the central government using a Top-Down approach to coerce the ODCDR of Makassar and other similar institutions to implement the nationally designed e-Government applications. To some extent, this is a reflection of an increase in bureaucratization (Ritzer, 1996).

On the one hand, some characteristics of Organic systems is somewhat manifested in the emerging data. This could potentially render e-Government implementation at the ODCDR of Makassar a Development Model. On the other hand, the strict control of central government over the ODCDR of Makassar and other similar institutions reflects a Coercive model. To qualify a Development Model according to the theoretical framework a Normative characteristic (Institutional Theory) is required, while in reality it is Coercive, which is related to Automation model.

Such phenomenon is not peculiar to the ODCDR of Makassar. This could reflect a general phenomenon in developing countries having paternalistic bureaucratic culture. In this case, although previous studies on which the theoretical framework was based on the context of developing countries, it overlooked the paternalistic culture of developing countries. The framework oversimplifies the fact by assuming that e-Government is always developed and implemented by the same institution. In reality, in developing countries where paternalistic culture is still strong and where local human resource capacity is low and local e-Government suprastructure such as leadership commitment (see Ask and Hatakka et al., 2008; Gronlund, 2002; Fidler, 2011; and Ray, 2011) is still weak, it is understandable if the central government inclines to use a supply-driven approach to developing e-Government applications. For Indonesian condition, this is especially justifiable given the urgent need to implement e-Government, on the one hand, and insufficient local capacity on the other. Based on the above discussion it is discovered that the e-Government implementation model at the ODCDR of Makassar is a Hybrid model of Pre-Development (see Figure 2) which is the cross-fertilization between Organic feature of the General Systems Theory and the Coercive feature of the Institutional Theory. This finding may be generalizable to local institutions in developing countries practicing paternalistic bureaucratic culture. This is especially true of Indonesian context, which recently undertook a major reform and was still to some extent in a transition period. The central government is inclined to take over the responsibility especially when local capacity is weak. In addition, the weak national e-Government grand design may have also contributed to this dominant central government as the central government wants to ensure interoperability of the e-Government systems across all relevant institutions nationwide. 


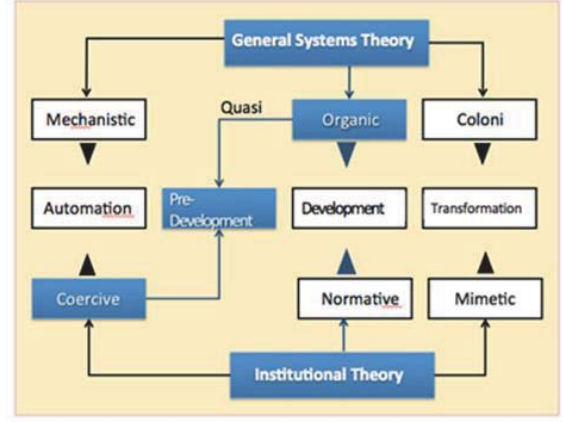

Figure 2. Empirical e-Government Implementation Model at the ODCDR of Makassar

\subsection{Ideal e-Government Implementation Model for the ODCDR of Makassar}

As the analysis above suggests, the ODCDR of Makassar currently has a hybrid e-Government implementation model referred to as Pre-Development. However, this hybrid model does not fit the ODCDR of Makassar due to at least three fundamental reasons. First, it can cause the ODCDR of Makassar to continue to be heavily dependent on the central government in terms of hardware, software, maintenance and training, thus impeding local initiatives, which could otherwise support sustainable development and implementation of e-Government. Second, sense of ownership will lack as the ODCDR of Makassar was not directly involved in the development process. This office was only involved in the form of providing constructive ideas for further development of the e-Government. Third, the ODCDR of Makassar will face problems in fulfilling its specific needs because the system was developed with the central government needs in mind.

The Automation Model is not suitable either for the ODCDR of Makassar. Automation is a model whereby the eGovernment is partially developed, where sub-systems are not integrated. Apart from being unable to provide long-term support, this Model is also expensive as the old system will be totally abandoned when the new one is implemented.

Neither is Transformative Model suitable for the ODCDR of Makassar. The Transformative Model is an eGovernment approach whereby the development process totally ignores the existing e-Government applications. This will be too radical a change for Indonesian bureaucratic culture known to have a high uncertainty avoidance index (see Hofstede's Culture Tools Country Comparison in geerthofstede.com). Instead, Indonesian bureaucracy favors harmony, balance, and security. It will also be expensive in terms of financial and technological investments.

Theoretically, e-Government at the ODCDR of Makassar will be more effective if a "Development Model" is adopted in its pure form (see Figure 3). Adopting this model means the ODCDR of Makassar designs and develops its own e-Government incrementally, which is the characteristic of Organic Model based on General Systems Theory. In addition, the development and implementation of e-Government is not the pressure of the central government or other external factors, but rather emanating from internal needs to improve its performance, which is the characteristic of Normative Model based on Institutional Theory. The combination between Organic and Normative metaphors produces the pure Development Model.

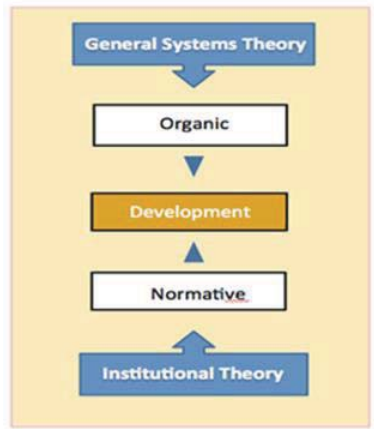

Figure 3. Ideal e-Government Implementation Model at the ODCDR of Makassar 
In order to adopt a Development Model, some preconditions have to be met. On the one hand, the capacity of the ODCDR of Makassar needs to be developed, including developing various suprastructure elements. First, leadership to influence all staff and stakeholders to use information and communication technology (ICT) needs to be developed. This commitment should not grow due to the central government pressure or that of other external entities. Rather, it should grow out of an internal desire to excel. Second, the culture of information technology has to be developed to get staff and citizens familiar with ICT-enhanced service environment. Third, policies to promote e-Government are required to force initially implementation of and eventually make all stakeholders familiar with the e-Government. Fourth, the organization needs to be strengthened. In this case, it is not the formal structure that needs strengthening but the structure of teamwork among people managing the day-to-day operation of e-Government. Fifth, the human resource competency needs to be developed to provide technical and managerial support effectively to the e-Government implementation.

For the human resource development, there is a need for knowledge transfer from the central government to the ODCDR of Makassar, including similar institutions in other regions. By the time learning has taken place and staff already can develop e-Government incrementally, their confidence to take initiatives will eventually grow. This is feasible because in the past the ODCDR of Makassar had been successful in developing its own Demographical Management Information Systems called Transitional-SIAK. Furthermore, the ODCDR of Makassar has proven to have the capacity to identify further development needs of SIAK that is to enable service transaction to be stored in the database and displayed in monitors reflecting real-time service transactions. This latest effort is undertaken jointly between staff of the ODCDR of Makassar and their counterparts in the neighboring Soppeng Regency. This is proof that a local collective capacity is present, supporting the argument that human resource development is a realistic way of building local capacity in designing and implementing e-Government. In turn, the central government should become increasingly aware of the existence of local capacity and should incrementally decrease its domination, which in turn will become a precursor of having a pure Development Model.

Knowledge transfer may also be undertaken by employing skilled contract staff. The successful deployment of contracted staff in the City of Surabaya is a case in point (see PKP2A II 2012).

On the other hand, the central government must cease its domination and instead supports local governments in developing their e-Government systems. To ensure interoperability of e-Government applications across local governments, the central governments must create standards in developing and implementing e-Government.

\subsection{Contextual-Participative e-Government Model}

The recommended "Development Model" is still too abstract for effective implementation. Therefore, the researcher proposes an improvement for the model to bridge the theoretical perspective and the empirical conditions. The researcher calls this improved model "Contextual-participative Implementation Model" as seen in Figure 4.

It is shown in Figure 4 that e-Government is not located in a vacuum. On the contrary, e-Government is deeply ingrained in its local context without violating nationally prescribed rules and citizen's needs.

From data analysis, it is evident that suprastructure as one of the determining factors is at the very fundamental position. Suprastructure is made of components such as leadership, organizational culture, policies and human resource management. This suprastructural foundation supports the management of citizen data and information both by the central government and local governments. To support the effectiveness and efficiency of citizens' data and information management, the support of ICT infrastructure is also required. In the next layer, e-Government is used in the day-to-day service delivery. In addition, electronic service delivery model will be evaluated by the central government in creating national policies regarding e-Government in the area of demographic and citizen data record. In turn, the citizen response and public policies cyclically become the basis for further developing the supporting layers for the e-Government. With this cycle, e-Government will develop sustainably because it is rooted in the local needs and characteristics and at the same time conforms to national policies, which is the essence of the pure "Development" implementation model. 


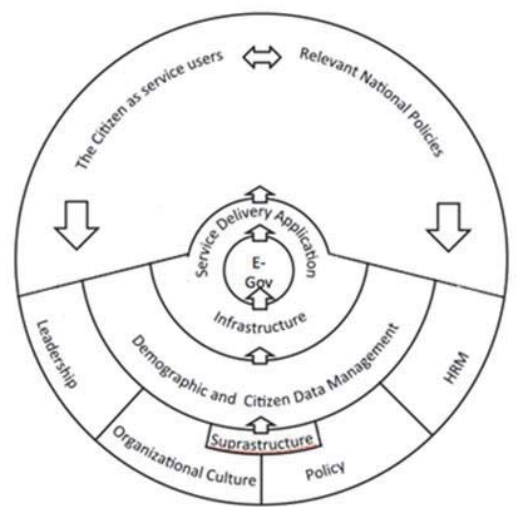

Figure 4. Contextual-Participative Implementation Model for e-Government at the ODCDR of Makassar

This strategy is reliable to push the ODCDR of Makassar towards the Development implementation model of eGovernment. A model which requires adequate organizational capacity to translate its own needs into e-Government solution and is capable of developing their own e-Government continuously without ignoring the higher level government policies and the needs of the people as service users.

\section{Conclusion}

This study has shed light to e-Government implementation model by demonstrating that contextual factors are important to consider. The e-Government implementation model in an organization under investigation (ODCDR of Makassar) deviates from alternative models prescribed by theories. The deviation appears to be related to the paternalistic culture of Indonesian bureaucracy.

Nevertheless, the study proposes that the theoretically prescribed "Development Implementation Model" better suits the ODCDR of Makassar. This ideal implementation model has an implication for the need of ODCDR to develop its internal capacity in building and implementing e-Government. This includes the strengthening of suprastructural elements such as leadership, organizational culture, supportive policy environment, and professional human resource management. It is also imperative for the central government to relax its control and reduce domination over ODCDR in local governments in terms of e-Government implementation.

To ensure effective implementation, a more elaborated operational model called "Contextual-Participative Implementation Model" is devised to bridge the organizational context and the theorized model. This improved model shows that e-Government-enhanced service delivery sits on layers of structures whereby suprastructure is located at the base, followed consecutively on top of it by demographic and citizen data management and ICT infrastructure. This layered structure mutually interact with relevant national policies and public demands.

\section{References}

Abugaza, A. (2014). Mengawal Program Makassar Smart City, Tribun Timur. Retrieved from makassar.tribunnews.com/2014/05/13/ mengawal-program-makassar-smart-city.

Ask, A., Hatakka, M., \& Gronlund, A. (2008). The Orebro City Citizen-Oriented E-Government Strategy. International Journal of Electronic Government Research, 4(4), pp. 69-88.

Boulding, K. E. (1956). General systems theory: The skeleton of science. Management Science, 2, pp. 197-208.

Carter, L., Schaupp, L. C., Hobbs, J., \& Campbell, R. (2012). E-Government Utilization: Understanding the Impact of Reputation and Risk. International Journal of Electronic Government Research, 8(1), pp. 83-97.

Chairunisa, F. (2010). Perkembangan E-Government di Indonesia: Potret, Hambatan dan Solusinya. Administrasi Negara, 16(4).

Chen, Y., Chen, H. M., Ching, R. K. H., \& Huang, W. W. (2007). Electronic Government Implementation: A Comparison between Developed and Developing Countries. International Journal of Electronic Government Research, 3(2), pp. 45-61.

DiMaggio, P. J., \& Powell, W. W. (1983). The Iron Cage Revisited: Institutional Isomorphism and collective rationality in organizational fields. American Sociological Review, 48(2), pp. 147-160.

Fidler, C. S., Kanaan, R. K., \& Rogreson, S. (2011). Barriers to e-Government Implementation in Jordan: The Role of Wasta. International Journal of Technology and Human Interaction, 7(2), pp. 9-20. 
MacAndrews, Collin (Ed.). (1986). Central government and local development in Indonesia. New York: Oxford University Press.

Miles, M. B., \& Huberman, A. M. (1994). Qualitative Data Analysis: An Expanded Sourcebook (2nd edition) Thousand Oaks, California: Sage.

Nygren, K. G. (2009). The rhetoric of e-government management and the reality of e-government work: the Swedish action plan for egovernment considered. International Journal of Public Information Systems, 2.

Pemkot Makassar. (2008b). Rencana Induk E-Government Kota Makassar. Makassar: Depkominfo.

Rana, N. P. (2011). Diversity and Diffusion of Theories, Models, and Theoretical Constructs in E-Government Research. Paper presented at the 10th IFIP WG 8.5 International Conference, e-Government 2011, Delft, The Netherlands.

Ray, S. (2011). Identifying Barriers to E-Government Services for Citizens in Developing Countries: An Exploratory Study. International Journal of Electronic Government Research, 7(3), pp. 79-91.

Ritzer, G. (1996). The McDonaldization of Society: An Investigation Into the Changing Character of Contemporary Social Life. Pine Forge Press.

Rohdewohld, Rainer. (1995). Public Administration in Indonesia. Merbourne: Montech.

Ronaghan, S. A. (2002). Benchmarking E-government: A Global Perspective. USA: United Nations Division for Public Economics and Public Administration and the American Society for Public Administration.

Salahuddin, M., \& A.Rusli. (2005). Information Systems Planning for e-Government in Indonesia. Paper presented at the International Conference on Innovations in Information Technology II.

The Economist Intelligence Unit, \& the IBM Institute for Business Value. (2007). The 2007 e-Readiness rankings: Raising the bar eReadiness rankings. USA: The Economist.

The Economist Intelligence Unit, \& the IBM Institute for Business Value. (2008). e-Readiness rankings 2008: Maintaining Momentum eReadiness rankings. USA: The Economist.

The Economist Intelligence Unit, \& the IBM Institute for Business Value. (2009). e-Readiness rankings 2009: The Usage Imperative eReadiness rankings. USA: The Economist.

Tim TIC Indonesia. (2010). Audit Fasilitas dan Program Layanan ICT SKPD, Perusda, Puskesmas, Kecamatan, dan Kelurahan di Lingkungan Pemerintah Kota Makassar. Makassar: Pemerintah Kota Makassar.

Tribun. (2009). Restoran Akan Dipasangi Sistem Pajak. Online Tribun Timur.

United Nations. (2002). Global e-Government Readiness Report: Towards Access for Opportunity. New York: United Nations.

United Nations. (2012). e-Government Survey: e-Government for the people. New York: United Nations

Venkatesh, V., Morris, M. G., Davis, G. B., \& Davis, F. D. (2003). User Acceptance of Information Technology: Toward A Unified View. MIS Quarterly, 27(3), pp. 425-478.

Verdegem, P., \& Verhoest, P. (2009). A User-oriented policy for ICT acceptance: The relative utility approach. International Journal of Public Information Systems, 3(2).

Wahid, F. (2011). Explaining History of e-Government Implementation in Developing Countries: An Analytical Framework. Paper presented at the 10th IFIP WG 8.5 International Conference, Delft Netherlands.

Wallström, A.., Engstrom, A., Salehi-Sangari, E., \& Styven, M. E. (2009). Public e-Services from the citizens' perspective: Adopting a market orientation. International Journal of Public Information Systems, 2(5).

Wartaegov. (2008). Daftar Pemenang Warta Ekonomi E-Government Award 2002 - 2008. Retrieved from http:/ljakarta.wartaegov.com lindex.php?option=com_wrapper\&view=wrapper\&ltemid=79

Wicaksono, D. A. (n.d). E-Government in Indonesia: The Opportunities and Challenges. Paper by Director of Kalla Lines IT Business Unit (Kalla Group, Indonesia) and Directorof Business Development PT. Infinite Universal Media. Jakarta-Indonesia 


\title{
An Intelligent System for Prioritising Emergency Services Provided for People injured in Road Traffic Accidents
}

\author{
Mohammad Taghi Taghavifard 1 \\ Sharareh Rostam Niakan Kalhori2 \\ Pegah Farazmand ${ }^{3 *}$ \\ Khatereh Farazmand ${ }^{4}$ \\ ${ }^{1}$ Department of Management, Faculty of Management and Accounting, Allameh Tabataba'i University, Tehran, Iran \\ ${ }^{2}$ Department of Health Information Management, Faculty of Allied Medical Science \\ Tehran University of Medical Sciences, Tehran, Iran \\ ${ }^{*}$ Department of Management, Faculty of Management and Accounting, Allameh Tabataba'i University, Tehran, Iran \\ ${ }^{4}$ Department of Health, Faculty of Health, Shahid Beheshti University of Medical Sciences, Tehran, Iran \\ ${ }^{*}$ Corresponding author: Pegah Farazmand, e-mail: farazmand.atu@gmail.com
}

Doi:10.5901/mjss.2016.v7n1s1p354

\section{Abstract}

Excessive road traffic accidents are the cause of referrals of a large number of injured people to hospitals. However, shortage of resources does not allow caring for all of them at the same time. Therefore, injured individuals should be prioritised by a triage unit. Patients with serious life-threatening conditions should be sent as the first priority to the emergency department to receive required care. This paper aims to design a triage model for categorising injured individuals using two different methods: Neural Network (NN) and Adaptive Neuro-Fuzzy Inference System (ANFIS). The models were built with a data set of 3015 data designed by Iranian medical experts and were based on patients' general appearance, vital signs and chief complaints. When a patient presents to the triage unit, the system analyses the data given and patient's emergency status can be reported straightaway. This reduces the triage time and the queue of patients at the emergency department. Both models were tested by 3 groups of data with a total number of 417 data. Reliability and validity were assessed. Results showed that overall ANFIS model performed better in categorising patients.

Keywords: Adaptive Neuro-Fuzzy Inference System (ANFIS), Neural Network (NN), Intelligent System, Traffic Accidents, Triage

\section{Introduction}

Accidents are inevitable events in daily life. Road traffic accidents threaten human life more than any other events. They cause apparent health and social problems in developed and developing countries. This becomes even more important considering that most of the victims are usually young and healthy (Jahangirfard et al, 2014). According to WHO ${ }^{1}$ reports, nearly 3400 people die on the roads every day. Tens of millions of people are injured or disabled every year (Pietrasik, 2014). Accidents result in Disability Adjusted Life Years (DALY), Years Life Lost (YLL) and Years Life Disability (YLD), imposing high pressure on health budgets of countries (World Health Organization, 2014). Iran deals with a lot of problems related to road traffic accidents which according to UNICEF²reports cause thousands of injuries and deaths every year and cost billions of dollars (UNICEF, 2014). Recent Iranian Legal Medicine's site statistics showed that number of deceased and injured people due to road traffic accidents in during 12 months of 2014 were 16872 and 304485, respectively (Iranian Legal Medicine Organization, 2014). According to Paravar et al (2013) and Tavakoli Kashani et al (2012), Iran has one of the highest rates of road traffic accident in the world and around 55 people die in Iran daily (Trend News, 2013).

The important fact is that due to a huge number of accidents, a large number of people with dangerous conditions are referred to hospitals every day and every hour. At the same time relatives might wish for their patients to be sent to the emergency department and considered as the first priority. Also, in some cases, two or more injured people are taken

\footnotetext{
1 -World Health Organization

2- United Nations International Children's Emergency Fund
} 